\title{
PARTICLE NUMBER (PN) MEASUREMENTS ON FLEX-FUEL VEHICLES WITH DI AND PFI ENGINES
}

\author{
Alexandre Olmos, Ricardo Banhara, Claudio M. Engler Pinto \\ General Motors Mercosul - Global Propulsion Systems \\ E-mails: alexandre.olmos@gm.com, ricardo.banhara@gm.com, \\ claudioengler.pinto@gm.com
}

\begin{abstract}
As a heritage from Diesel vehicles, the EURO 6 Light Duty emission standards introduced limits for particle number (PN) of GDI engines. Given the concern of the extremely small particles on health effect, the same limits were set $\left(6.0 \times 10^{11} \mathrm{\#} / \mathrm{km}\right)$ for both diesel and GDI cars. In Brazil, the current phase for light vehicles of PROCONVE L6 enforced particulate matter (PM) mass emission standard for Diesel vehicles only, applying the limits of $25 \mathrm{mg} / \mathrm{km}$ for passenger cars and $30 \mathrm{mg} / \mathrm{km}$ for commercial vehicles. Similar to the European concern, even not considering yet the particle number (PN) emissions, future Brazilian phase L7, which is under study, considers a significant reduction on the limit of the particulate matter (PM) mass emission, from current limits down to $6 \mathrm{mg} / \mathrm{km}$ for both Diesel and DI engines, for passenger and commercial vehicles. In the goal of generating reference data to foster the important discussion of (PN) emissions in Brazilian passenger vehicles, this article discusses (PN) measurements of Flex-Fuel Vehicles equipped with direct injection (DI) and port fuel injection (PFI) engines, fueled with ethanol (E100) and gasohol (E22). The mechanisms and parameters which influence the particulates formation are discussed according to the bibliography and the advantages that Ethanol usage brings to human health is highlighted. This study shows interesting comparative results of (PN) and can be used as reference for future emissions regulations of Flex-Fuel vehicles in Brazilian market.
\end{abstract}

\section{INTRODUCTION}

World Health Organization (WHO) declared on its 2016 update [1] that more than $80 \%$ of people living in urban areas that monitor air pollution are exposed to elevated levels of particulate matter that exceed the air quality limits. This update on air quality database registers that only $2 \%$ of cities in low and middle-income countries with more than 100,000 inhabitants meet WHO air quality guidelines. In high-income countries, the scenario increases to $44 \%$. Similarly, according to Irish Environmental protection agency [2], the WHO estimates show that more than 400,000 premature deaths are attributable to poor air quality in Europe annually. Locally in Brazil this matter is not different, the numbers of deaths are also scary. Figures from the Institute for Health Metrics and Evaluation, 2016 related to 2015 showed that the cause of 52,284 deaths were related to exposure to particulate matter (fine particles, $\mathrm{PM}_{2.5}$ ) [3]. Still according to WHO the Ambient Air Quality Database from 2014 reports annual average PM2.5 
concentrations in 40 Brazilian cities [4]. It shows that only one city is below the WHO air quality guideline of $10 \mu \mathrm{g} / \mathrm{m} 3$, the other 39 cities are exceeded, figure 1 .

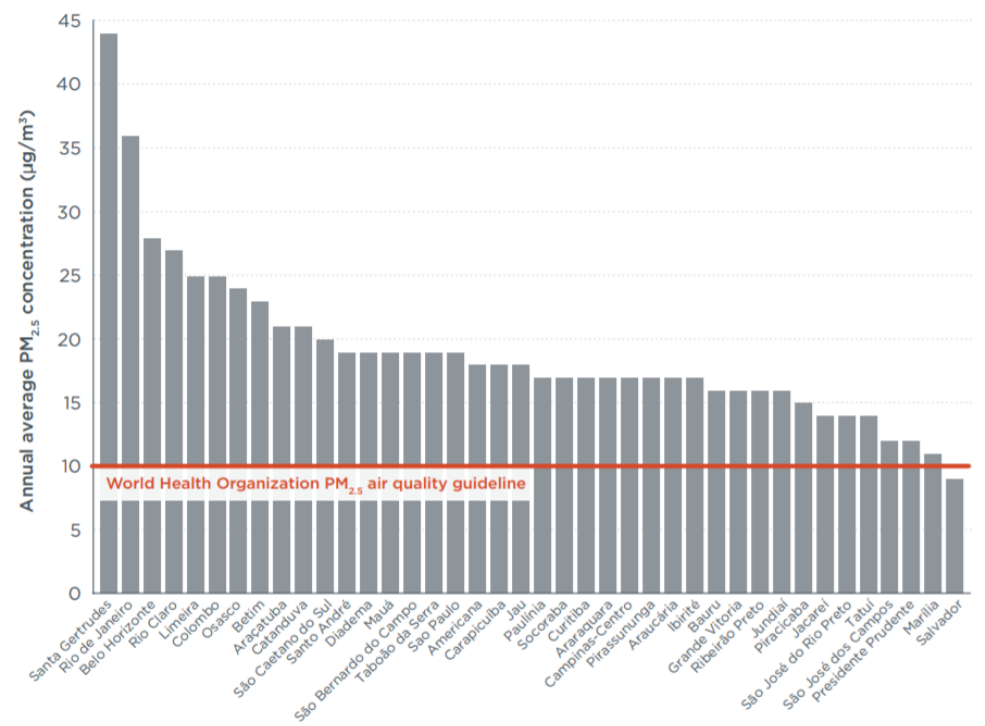

Figure 1: Annual Mean $\mathrm{PM}_{2.5}$ concentrations in Brazilian cities [3].

Regarding particulate matter produced by flex fuel vehicles, Salvo et al. presented a recent paper with an investigation about the effect of ethanol - gasohol fuels usage shifts in ultrafine particles generation (from $6 \mathrm{~nm}$ to $100 \mathrm{~nm}$ diameter particles) [5]. It was found that the shift from gasohol to ethanol reduced the amount of ultrafine concentration in on third and the opposite occurred when flex fuel vehicles shifted from ethanol to gasohol.

Based on all of these facts, the control of PM pollution is extremely important for human well-being. The effect of ethanol in flex fuel vehicles, as well as the injection technology, PFI or DI, are relevant factors in this topic. This paper aims to contribute in this discussion by generating data with current production vehicles.

\section{DEFINITION \& SOURCES}

\subsection{Definitions of Particulate Matter \& Particle Number}

It is important to disambiguate the different meanings that the term particulate matter has been subjected to. Sometimes, the different terms Particulate Matter, Particulates, Particles, PM, PN, Smoke and Soot can be treated interchangeably, on emissions discussions for general purpose, without the rigor of the academic, while discussions of emissions measurements use a distinction between Smoke, PM and PN.

Regarding to this, according to EPA [6] Particulate Matter can be also called particle pollution, which is defined by a mixture of solid particles and liquid droplets found in the air. Some of them are big enough to be seen with the naked eye, such as dust, soot, or smoke, while others are so tiny that they can only be seen on an electronic microscope. 
A good explanation is given by EEA [7] when they outline Particulate Matter (PM) as a collective name for fine solid or liquid particles added to the atmosphere by processes at the earth's surface. Particulate matter includes dust, smoke, soot, pollen and soil particles. Related to Smoke, it is defined as an aerosol, consisting of visible particles and gases, produced by the incomplete burning of carbon-based materials, such as wood and fossil fuels. As for Soot, it is an impure black carbon with oily compounds obtained from the incomplete combustion of resinous materials, oils, wood, or coal. At last, the EEA definition for Particle Number (PN) is a variety of measurements characterizing the number of particles in an aerosol sample.

\subsection{Particulate Matter Sources}

Particulate matter can come from either natural or anthropogenic source. Natural source is generated by the nature itself, such as salt spray, wildfires, sand, dust, volcanoes, etc. It is considered an anthropogenic source anything that is caused by humans or their activities, highlighting the products of combustion, agriculture, among others. Figure 2 demonstrates that anthropogenic sources, in 2011, were responsible for $44 \%$ of the $\mathrm{PM}_{2.5}$ emissions by mass, while natural sources were responsible for $56 \%$.

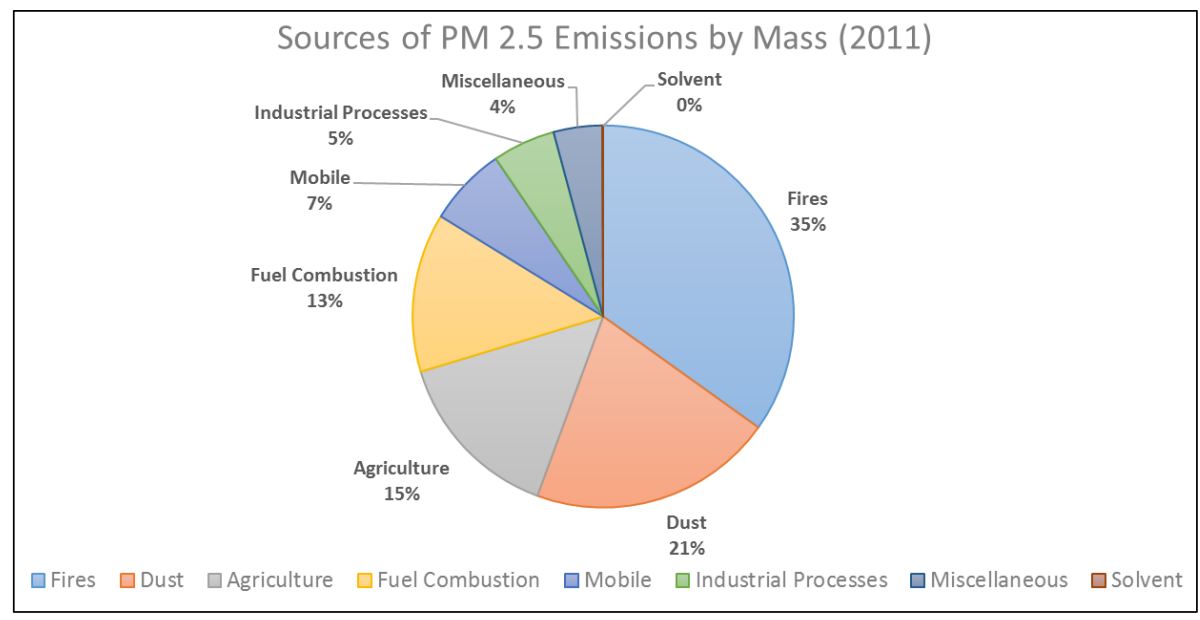

Figure 2: Contribution of the natural and anthropogenic sources on PM 2.5 emissions [6].

Particulate matter is divided in two distinct categories, primary and secondary. Primary particles are directly emitted and secondary particles form as a result of atmospheric reactions involving gaseous emissions. Both are regulated, though secondary particles are regulated indirectly.

\section{PARTICULATE MATTER IN ENGINE EXHAUST AND IMPORTANCE}

\subsection{Composition}

Once diesel fuel is one of the main responsible for the particulate matter emissions, its composition is highlighted. According to Johnson et al. [8], particle matter diesel emissions is divided in three phases, gas, solid and liquid/vapor phases. The gas phase emission includes $\mathrm{NOx}, \mathrm{CO}$, and sulfur dioxide $\left(\mathrm{SO}_{2}\right)$. Figure 3 demonstrates the components of the solid and liquid/vapor phases. It shows that solid phase emissions are initially constituted of small $(10-80 \mathrm{~nm})$ solid carbon cores $-\mathrm{SOL}-$ and 
agglomerates $(50-1,000 \mathrm{~nm})$. The liquid/vapor phase is composed of the organic, named SOF - Soluble organic fraction - and hydrocarbon component and sulfate $\left(\mathrm{SO}_{4}\right)$, which can be removed by water. Part of the hydrocarbons are absorbed onto the SOL, and part of them remains as a vapor.

Generally speaking, the whole composition involves some hydrocarbons absorbed in an agglomerate of SOL. Those hydrocarbons can be removed by the SOF, which is an organic solvent of the hydrocarbons.

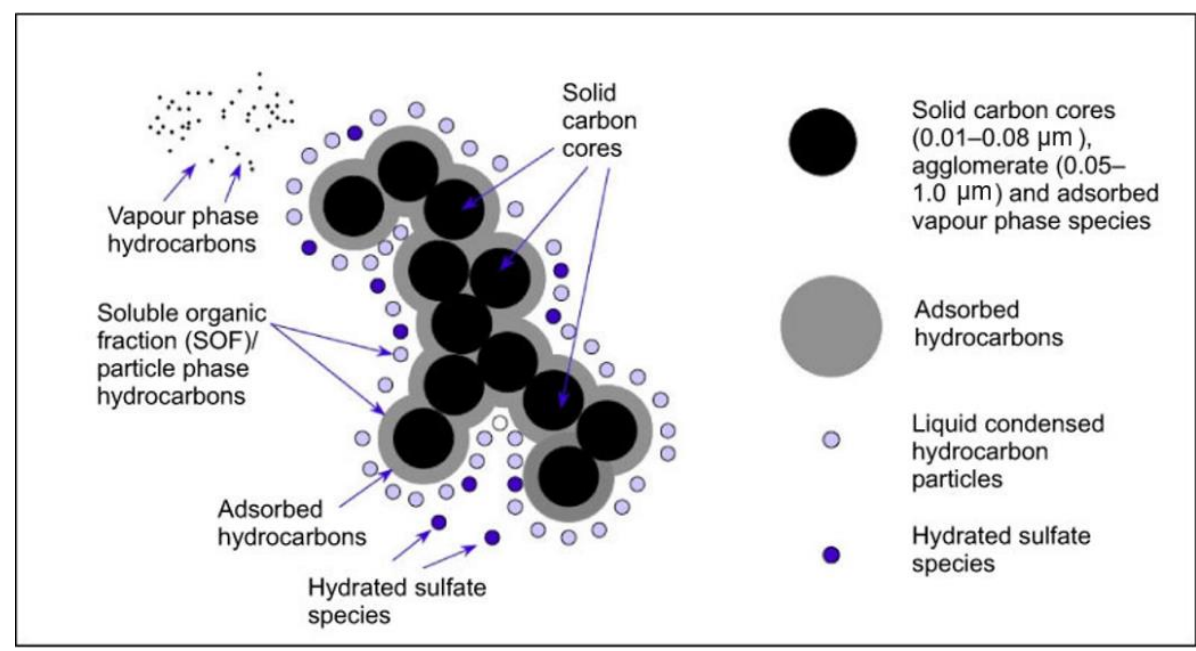

Figure 3 - Schematic of Diesel Particles and Vapor Phase Compounds [8].

\subsection{Characterization}

It is noticeable that the European Regulatory Agency evolved when went from massbased air pollution regulation for particulate matter to particle number, that is more accurate about the physical properties of the particulate matter regarding to the effects on human health. Surface area can also be measured as a parameter to be regulated.

There is an important correlation between mass, particle number and surface area of the particulate matter that is explained by Kittelson [9], which includes the size range defined for the atmospheric particles as $\mathrm{PM}_{10}$ (diameter $<10 \mu \mathrm{m}$ ), fine particles $\mathrm{PM}_{2.5}$ (diameter $<2.5 \mu \mathrm{m}$ ), ultrafine particles $\mathrm{PM}_{0.1}$ (diameter $<0.10 \mu \mathrm{m}$ or $<100 \mathrm{~nm}$ ), and nanoparticles (diameter $<0.05 \mu \mathrm{m}$ or $<50 \mathrm{~nm}$ ). A diesel fuel distribution is exposed in figure 4, and according to the author, distribution from a spark ignition engine would be similar but with relatively less material in the accumulation mode region.

The practical meaning of this demonstration is that the total of mass does not reflect properly the number of small particles, which are the ones harmful to human health. 


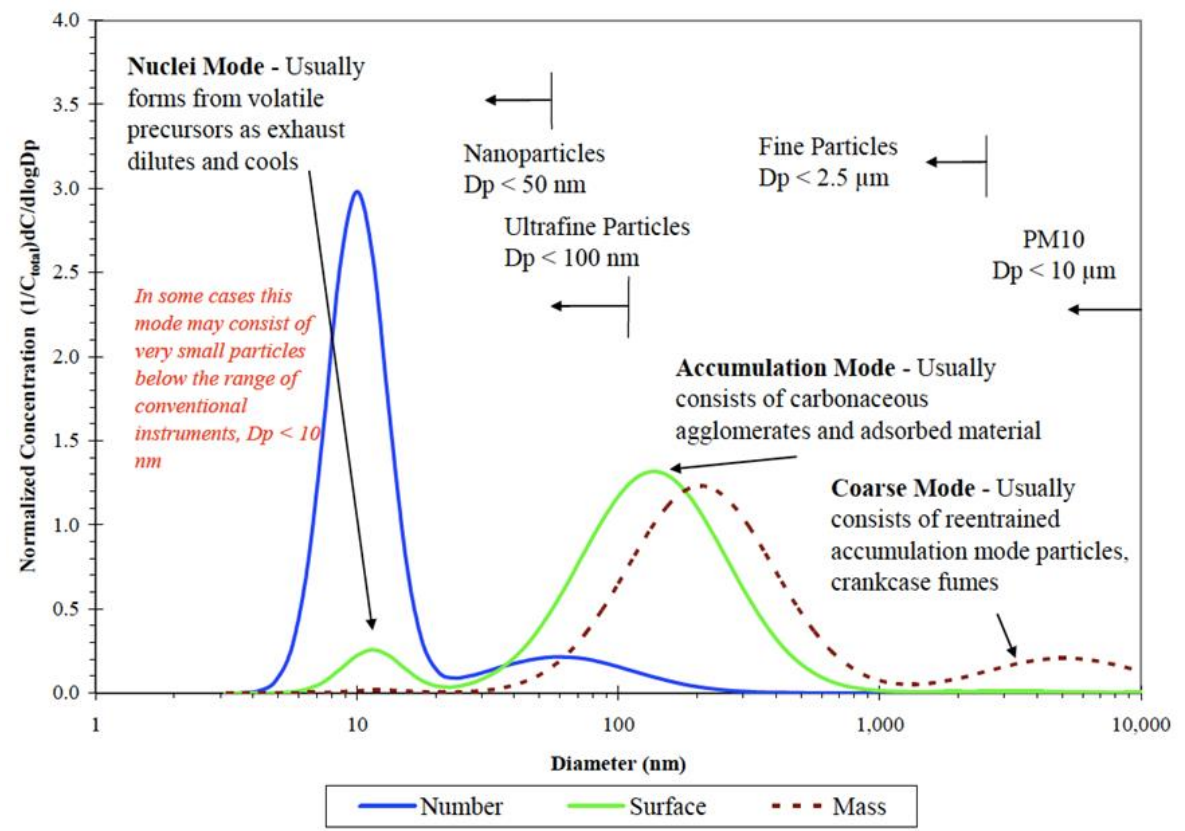

Figure 4: Typical PM Size Profile of the Emissions from a Diesel Engine Indicating the Nuclei and Accumulation Mode Size Regions [9].

Complementing the explanation related to the size of the particles, EPA [6] provides a helpful description about the size of the particles when compared to a human hair. It shows that the average human hair is about $70 \mu \mathrm{m}$ in diameter - making it 30 times larger than the largest fine particle. EPA calls the particles sizes as: $\mathrm{PM}_{10}$ : inhalable particles, with diameters that are generally $10 \mu \mathrm{m}$ and smaller; $\mathrm{PM}_{2.5}$ : fine inhalable particles, with diameters that are generally $2.5 \mu \mathrm{m}$ and smaller; PMo.1, with diameters that are generally $0.1 \mu \mathrm{m}$ and smaller, as seen on figure 5 .

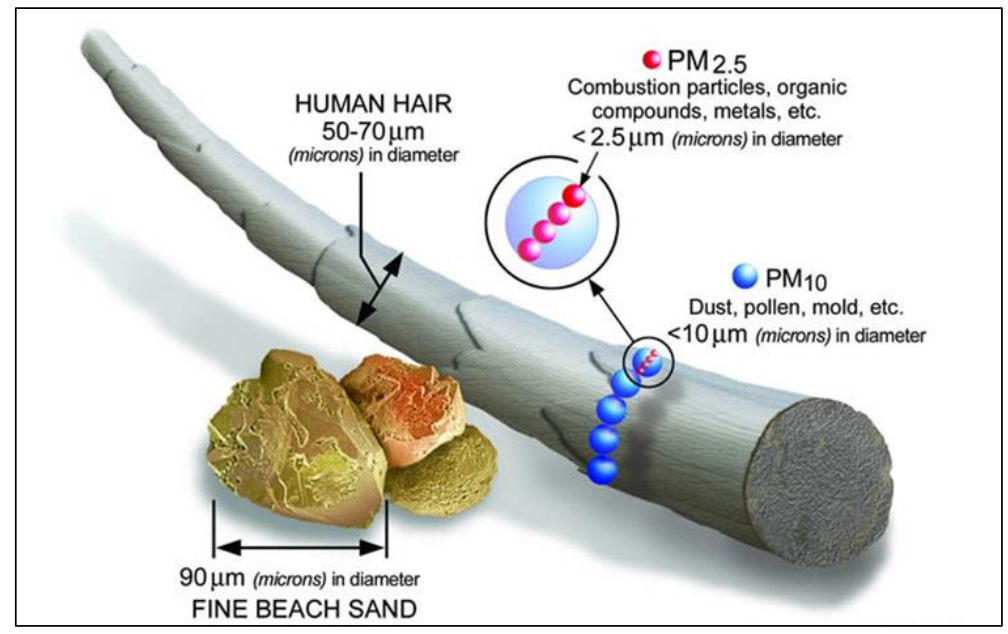

Figure 5: Size comparison between human hair and particle matter [6].

\subsection{Impact on health and climate change}

Several studies about health of the past decades have pointed out strong evidences that elevated levels of particulate matter air pollution are associated with increased cardiovascular and respiratory diseases [10]. In this matter, small particles from engines are particularly worrisome. 
January 2013 issue of Nature magazine [11] stated that soot is a major contributor to climate change. Similarly, defined that soot, also known as black carbon, "is the second most important human emission in terms of its climate forcing in the present-day atmosphere; only carbon dioxide is estimated to have a greater forcing" [12]. Bullis, expound is his article "Cleaning Up Diesel Trucks and Cooking Stoves Could Reduce Climate Change" [13] that selective reductions of particulate pollution might help the climate change issue.

\section{REGULATIONS AND TEST CYCLES}

In the U.S. and Europe, $\mathrm{PM}_{10}$ and $\mathrm{PM}_{2.5}$ are currently regulated.

\subsection{US Emissions Standards}

In the United States Emissions standards have two bodies regulating emissions - the EPA and CARB. Both regulate particulate matter using a mass limit. EPA established Tier III 3mg/mi on FTP driving cycle in 2017, while CARB took LEV III $3 \mathrm{mg} / \mathrm{mi}$ in 2017, 1 mg/mi (begin phase-in 2025), also on FTP driving cycle. Figure 6.
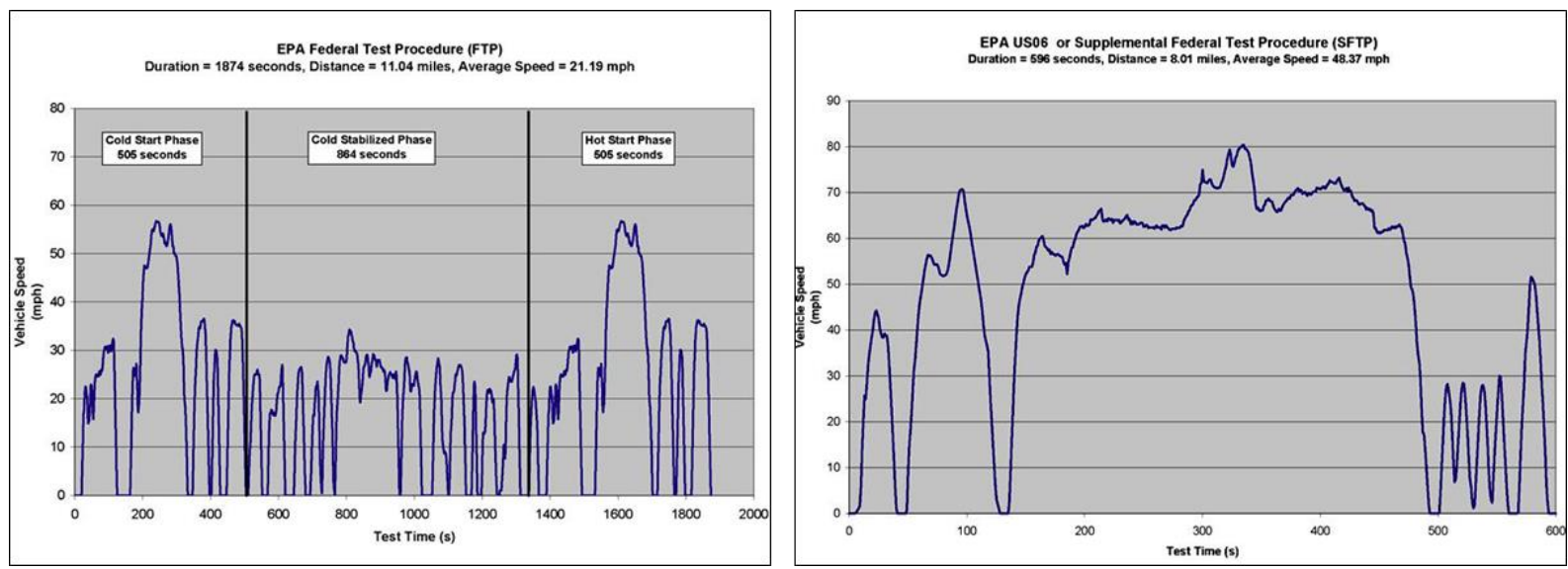

Figure 6: Speed profile of FTP 75 and US 06 driving cycles.

\subsection{European Emission Standards}

The European Union implemented a Particle Number limit in addition to a mass standard. Started with Euro5b, Diesel vehicles were limited to $6 \times 10^{11}$ particles $/ \mathrm{km}$. For Direct Injection Gasoline engines, Euro 6, in 2014, initially met a limit of $6 \times 10^{12}$ particles $/ \mathrm{km}$, and from 2017, with Euro $6 \mathrm{c}$ met full standard of $6 \times 10^{11}$ particles $/ \mathrm{km}$. Particle number standard must be met in addition to the $5 \mathrm{mg} / \mathrm{km}$ particle mass standard. NEDC driving cycle has been replaced in 2017 by WLTP and the RDE onroad cycle was included as a supplemental test to verify real-world compliance with emissions limits.

Particulate measurement protocol - PMP - was established to very carefully define the sampling and measurement conditions in an attempt to obtain repeatable measurements. In order to achieve repeatable measurements, only solid particles are 
counted, volatile particles are removed by using an evaporation tube or thermodenuder and, to further ensure volatile particles are not counted, only particles between $23 \mathrm{~nm}$ and $1,000 \mathrm{~nm}$ are counted.

\section{FORMATION IN ENGINES}

Basically, the formation of the soot happens during the combustion of hydrocarbons. In the presence of oxygen (stoich or lean) and sufficient temperature, however, most of it will be oxidized. In rich flames, there is insufficient oxygen to oxidize all of the soot - that which remains is emitted.

The mechanism of the formation of the soot particles in diesel engines [14] follows a sequence which starts with pyrolysis, that is the decomposition of the molecules, brought about by high combustion temperatures. As a result, the platelets are formed and then become microscopic crystals, also known as crystallite. All the crystallites together transform in turbostratic particles. After that, there is the coagulation phase and the surface growth. The grown particles, later on, form an aggregation. As mentioned in figure 3 , there is the absorption and condensation of hydrocarbons. The increasing on the size of the particles along the mechanism of their formation is also shown on figure 7 . They start at $0.35 \mathrm{~nm}$ as platelets and end from 0.1 to $10 \mu \mathrm{m}$ at the aggregation of the grown surface particles.

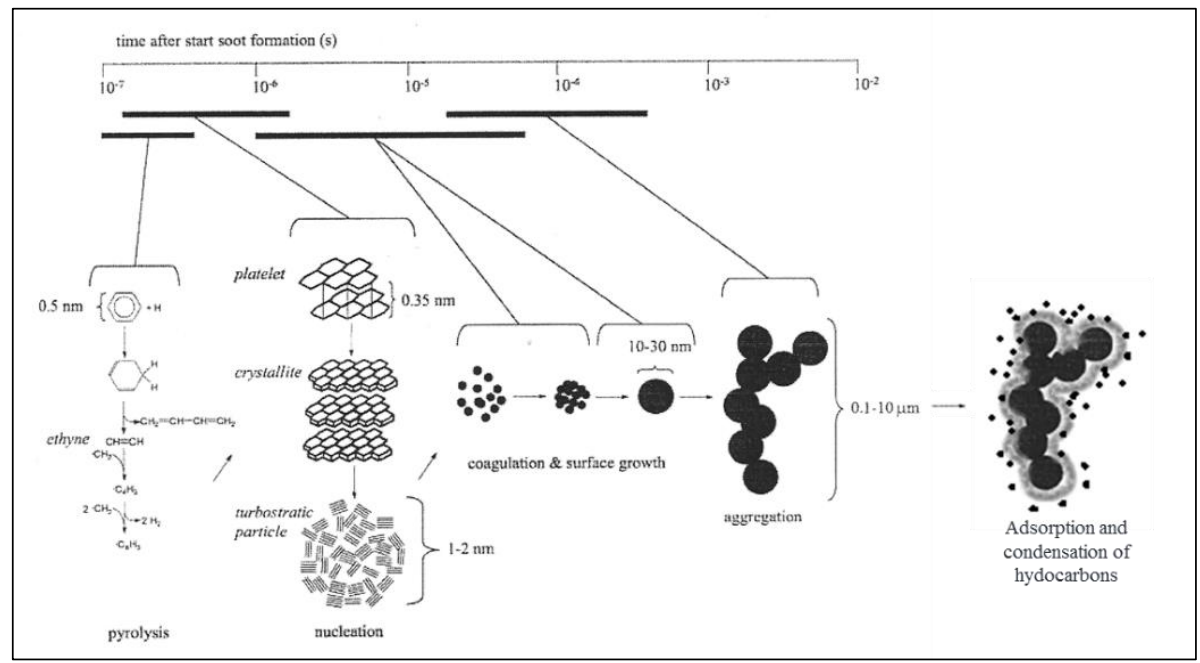

Figure 7: Schematic mechanism of the formation of soot particles [14].

Generally speaking, in internal combustion engines, soot forms as a result of reactions in localized fuel-rich regions. While the mechanisms differ, this is true for both Diesel and Gasoline engines. In Diesel engines soot forms on the fuel-side of the diffusion flame.

In Gasoline engines, the fuel-rich regions may be split into two categories: liquid fuel in-cylinder, in which either aerosol droplets or surface films (or pools) of fuel result from poor fuel spray characteristics; and pockets of fuel-rich mixture, that is a result of poor mixing.

In DI engines the sources of PM formation are directly related to the combustion chamber surfaces. Its influence is impacted by the following characteristics: (1) piston 
crown (poorly chosen injection timing); (2) bore liner (excessive penetration may be due to poorly chosen injection timing, spray pattern, insufficient or mismatched charge motion); (3) combustion chamber roof (direct - poor spray pattern, indirect - may splash off of the piston); (4) intake valves (Incorrect spray pattern); (5) liquid droplets in the chamber volume (poor atomization from poorly designed injector or excessive deposits on the injector); (6) residual fuel on the injector tip (may be leaking, have an excessive sac volume, or fuel may be adsorbed by deposits); (7) fuel (liquid or vapor) may collect in the top land crevice; and (8) vapor-phase fuel-rich pockets (poor mixing - may be due to poor injection or charge motion characteristics). Figure 8 [15].

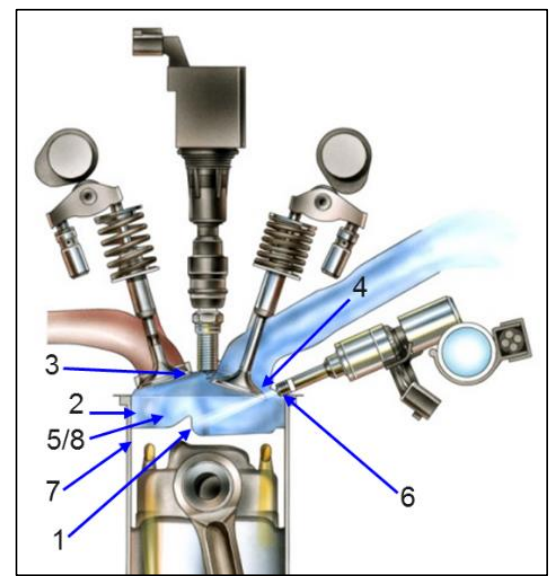

Figure 8: Impact on combustion chamber surfaces as a source of PM formation in DI engines [15].

\section{FACTOR INFLUENCING SOOT FORMATION}

As already described the soot formation is influenced by several parameters such as temperature, air-fuel ratio, chamber pressure, fuel composition, residence time and addition of additives.

The soot formation, as many experimental studies have shown [16] [17], increases with combustion temperature in the region below $1500 \mathrm{~K}$, since the pyrolysis and crystallite rate production depends mainly on temperature, which contributes to aggregation growth and finally to form the structure of the adsorption and condensation of hydrocarbons. Differently, in the high temperature region around 1500 to $1700 \mathrm{~K}$, where the oxidation process is dominant the soot formation is greatly reduced, figure 9. Many experimental investigations confirm that temperature is the dominant influence parameter on soot formation even at elevated pressure levels.

Other parameter that strongly impacts the soot formation is the air-fuel ratio. In general, the soot mass and particle diameter increase with the equivalence ratio (EQR) as shown in figure 9 with the combined effect of temperature and air-fuel ratio (as the $\mathrm{C} / \mathrm{O}$ ratio). It can be observed a critical $\mathrm{C} / \mathrm{O}$ ratio below which no soot is formed. 


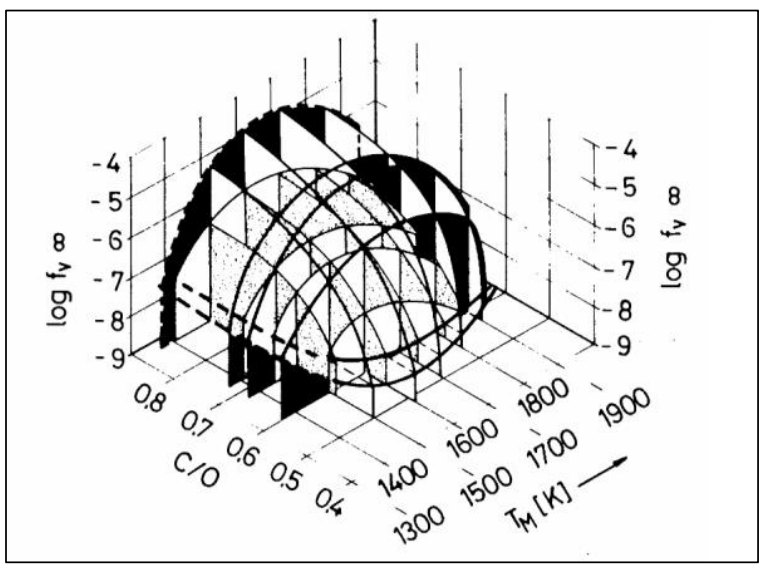

Figure 9: Soot volume fraction as function of the molar ratio $\mathrm{C} / \mathrm{O}$ and the temperature behind a laminar premixed ethylene/air flame at a pressure of 10 bar [16].

The type of fuel and their composition is another important parameter. As the aggregation process results from the fuel thermal composition, its chemical structure strongly impacts the kind and quantity of products. The soot formation increases with the hydrocarbon chain size. Polyaromatics and aromatics chains produce more aggregation than alkenes [16]. In this way, E100 fuel has chemically less tendency to soot formation than E22 fuel since its chemical structure is small $\left(\mathrm{C}_{2} \mathrm{H}_{6} \mathrm{O}\right)$ and without aromatic molecules (E22 fuel contains 15 to $35 \%$ in volume of aromatic chain).

As result of this efficiency on soot formation, some recent studies have shown the environmental and social benefits of E100 fuel. Salvo et al. [5] reported that the ultrafine particle (7-100 nm diameter) fall by one-third during the morning commute when higher gasoline price induces 2 million drivers in the real-world megacity of São Paulo to refuel their vehicle with E100 fuel instead of E22 fuel. The opposite trend was measured for fueling shifts from E100 to E22, figure 10.

In addition, the soot formation can also be changed by additives. When inert additives like $\mathrm{H}_{2} \mathrm{O}, \mathrm{CO}_{2}$ or $\mathrm{SO}_{2}$ are added to the fuel (from dilution via internal or external gas recirculation) the profiles of species concentration and temperature are changed, decreasing the shooting tendency and overriding the temperature effect. Studies showed that the addition of water is an efficient way to reduce the soot formation [17].

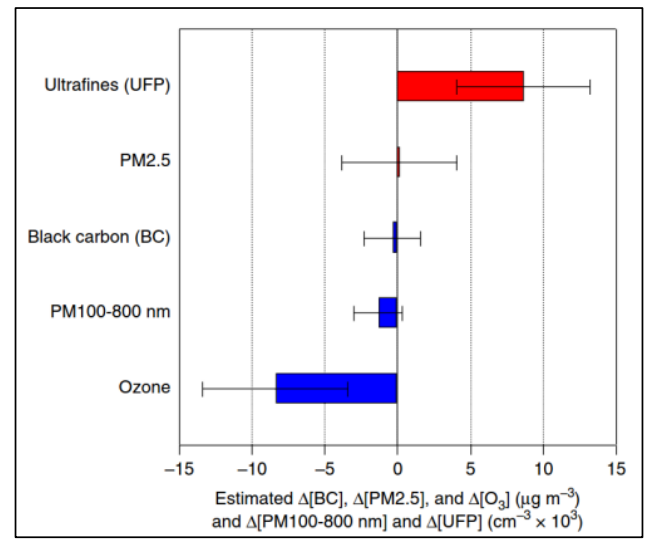

Figure 10: Estimated changes in pollutant concentrations in the São Paulo metropolitan area as the gasoline share in the flex-fuel fleet rises from 30 to $80 \%$ points [5]. 


\section{MITIGATION}

One way to mitigate particulate matter is by reducing engine-out emissions. Design and calibration efforts can be aimed at reducing the amount of particulate matter entering the exhaust stream. Related to exhaust aftertreatment, the use of devices in the exhaust stream is necessary to capture or oxidize the particles after they have entered the exhaust stream. Unfortunately, it is not totally effective, because it is tightly dependable on engine out reductions and generally it has larger impacts on vehicle performance and/or fuel consumption, and requires the use of particulate filters. An example of the efforts that come from improvements obtained on engine hardware combined with improvements made on engine calibration, in order to reduce the PN emissions [18] on a Gasoline DI engine at NEDC driving cycle, is shown on figure 11. These improvements together achieved $78 \%$ reduction on PN emissions at NEDC driving cycle. The results of this study demonstrated that the majority of the particulates are created during the cold start and at transient accelerations during cold engine operation. The contribution of each work package used for the huge reduction of particulate emissions are as follows: cold start 10\%; catalyst heating $10 \%$; transients during cold engine operation $60 \%$; steady state and transient operation of a hot engine $20 \%$. Details of the PN formation mechanisms, calibration actions and influencing hardware related to each of these work package are shown on table 1.

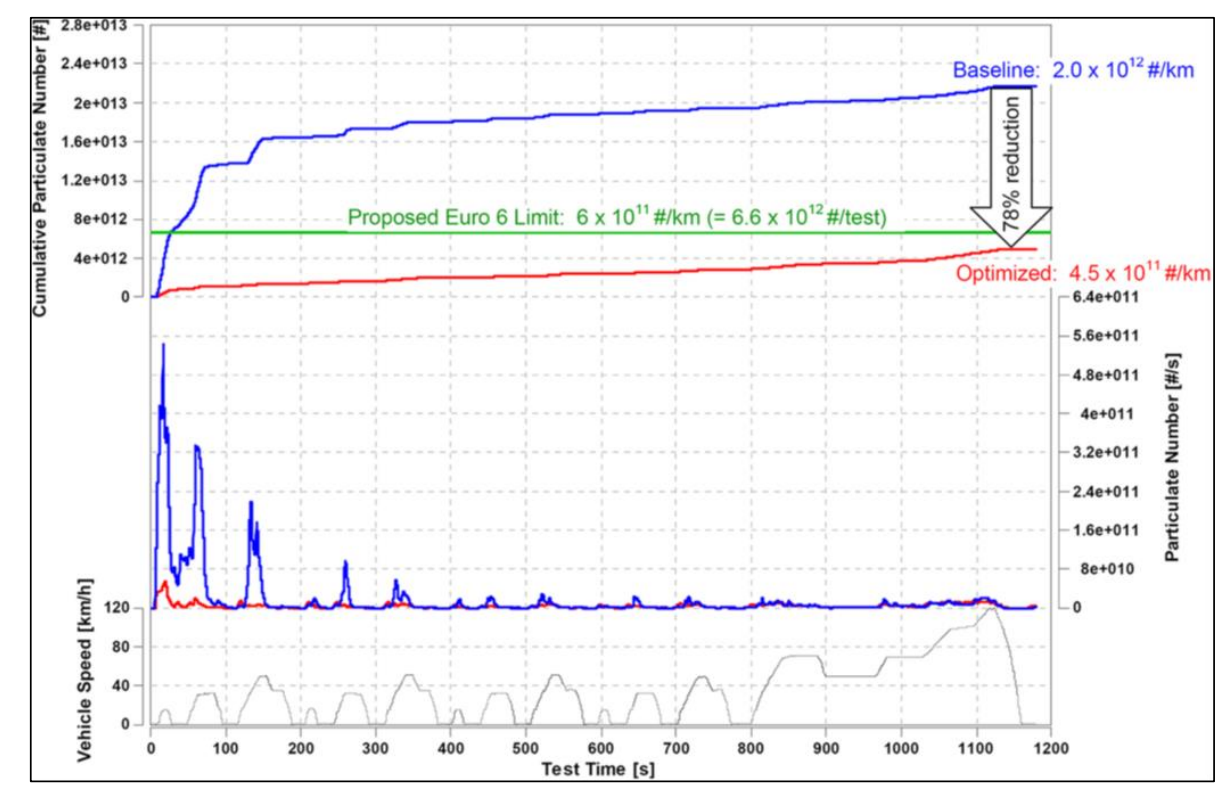

Figure 11: Particulate number results of DI engine at NEDC driving cycle. Euro-5 baseline versus engine optimized for Euro-6 PN emissions [18]. 


\begin{tabular}{|c|c|c|c|}
\hline Work Package & Mechanism Of PN Formation & Calibration Actions & Influencing Hardware \\
\hline Cold Start & $\begin{array}{l}\text { Insufficient mixture preparation } \\
\text { Droplet accruement } \\
\text { Wall wetting }\end{array}$ & $\begin{array}{l}\text { High pressure start } \\
\text { Multiple injection } \\
\text { Optimized injection } \\
\text { settings }\end{array}$ & $\begin{array}{l}\text { Piston geometry } \\
\text { Injector } \\
\text { High pressure pump } \\
\text { Fuel rail volume } \\
\text { Combustion chamber } \\
\text { geometry } \\
\text { Fast synch cam wheel }\end{array}$ \\
\hline Catalyst Heating & $\begin{array}{l}\text { Insufficient mixture preparation } \\
\text { Incorrect injection timing } \\
\text { Wall wetting } \\
\text { Stratification effects }\end{array}$ & $\begin{array}{l}\text { PN optimized injection } \\
\text { strategy } \\
\text { Multiple injection } \\
\text { Rail pressure } \\
\text { Camshaft position } \\
\text { Ignition timing } \\
\end{array}$ & $\begin{array}{l}\text { Piston geometry } \\
\text { Injector } \\
\text { High pressure pump } \\
\text { Combustion chamber } \\
\text { geometry } \\
\text { Camshaft } \\
\end{array}$ \\
\hline Cold Transient & $\begin{array}{l}\text { Insufficient mixture preparation } \\
\text { Incorrect injection timing } \\
\text { Wall wetting } \\
\text { Stratification effects } \\
\text { Too rich air/fuel ratio }\end{array}$ & $\begin{array}{l}\text { Dynamic calibration of } \\
\text { injection settings } \\
\text { Multiple injection } \\
\text { Rail pressure } \\
\text { Camshaft position } \\
\text { Ignition timing } \\
\end{array}$ & $\begin{array}{l}\text { Piston geometry } \\
\text { Injector } \\
\text { High pressure pump } \\
\text { Combustion chamber } \\
\text { geometry } \\
\text { Camshaft } \\
\end{array}$ \\
\hline $\begin{array}{l}\text { Warm Transient \& } \\
\text { Steady State }\end{array}$ & $\begin{array}{l}\text { Insufficient mixture preparation } \\
\text { Incorrect injection timing } \\
\text { Wall wetting } \\
\text { Stratification effects } \\
\text { Too rich air/fuel ratio }\end{array}$ & $\begin{array}{l}\text { Steady state injection } \\
\text { strategy } \\
\text { Multiple injection } \\
\text { Rail pressure }\end{array}$ & $\begin{array}{l}\text { Piston geometry } \\
\text { Injector } \\
\text { High pressure pump } \\
\text { Combustion chamber } \\
\text { geometry } \\
\text { Switchable water pump }\end{array}$ \\
\hline
\end{tabular}

Table 1: Influence of engine calibration and hardware on the PN-result [18].

\section{EXPERIMENTAL METHOD}

Once exposed the mechanisms and characteristics of the particulate matter and its importance and relation with the human health and climate change, developed countries adopted regulations for a very careful PN control. Considering PN is generated in all engine technologies, and with the use of all fuels, it is certain that discussions about PN emissions for passengers' vehicles in Brazil will eventually consider Flex-Fuel engines of all injection technologies that run with E100 and E22, and any blend that comes from that. As an attempt to provide reference data to help the initial discussions, a group of tests were conducted on four normal production FlexFuel vehicles, fueled with E100 and E22, focusing on PN emissions on Brazilian standard driving cycle NBR6601 (EPA75). Those vehicles belong to two distinct groups of Flex-Fuel engine technologies, DI and PFI.

All measurements were performed on chassis dynamometer (48-inch roller diameter) at GM Mercosul Emissions Laboratory configured with Particle Number Counter (PNC) model AVL 489 which works with the particles diameter between $23 \mathrm{~nm}$ to $2.5 \mu \mathrm{m}$, according to UNECE Regulation 83 (Light Duty Vehicles), figure 12.

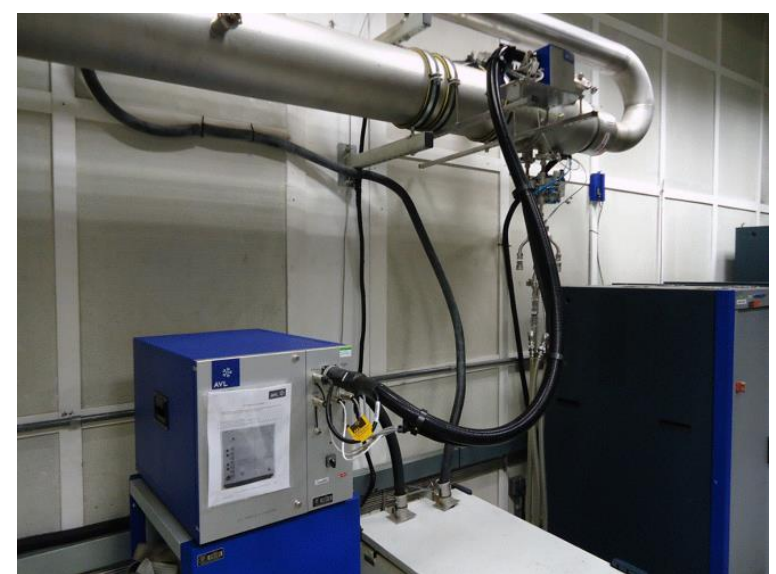

Figure 12: PNC installed in the CVS dilution tunnel. 
Two sets of Dl engines and one PFI engine were used in this study, according to table 2 .

\begin{tabular}{|c|c|c|c|}
\hline Injection Type & Test Vehicle & Test Fuel & Vehicle Category \\
\hline \multirow{3}{*}{ DI \#1 Flex } & A & $\begin{array}{c}\text { E100 } \\
\text { E22 }\end{array}$ & \multirow{2}{*}{ Passenger } \\
\cline { 2 - 3 } & B & $\begin{array}{c}\text { E100 } \\
\text { E22 }\end{array}$ & \\
\hline DI \#2 Flex & C & $\begin{array}{c}\text { E100 } \\
\text { E22 }\end{array}$ & Light Commercial \\
\hline PFI Flex & D & $\begin{array}{c}\text { E100 } \\
\text { E22 }\end{array}$ & Passenger \\
\hline
\end{tabular}

Table 2: Distribution of tests comparing injection technologies and fuels.

A total of 26 tests were run to generate all test batches and allow the comparison between different injection technologies and fuel blends.

\section{RESULTS FROM DI AND PFI FLEX-FUEL VEHICLES}

For the measurements with DI engines, two normal production passenger vehicles of the same model were tested, both equipped with the same engine type (vehicle A run 3 test batches and vehicle B run 6 test batches with each fuel), and also one light commercial vehicle with a different DI engine (1 test batch with each fuel), figure 13. Another passenger vehicle assembled with a PFI engine was tested (1 test batch with each fuel), figure 14 .

The results of this research showed that $\mathrm{PN}$ emissions with E100 fuel is much lower than PN emissions with E22 fuel in all tests. E100 PN emissions with both DI and PFI engines are lower, as seen in figures 13 and 14.

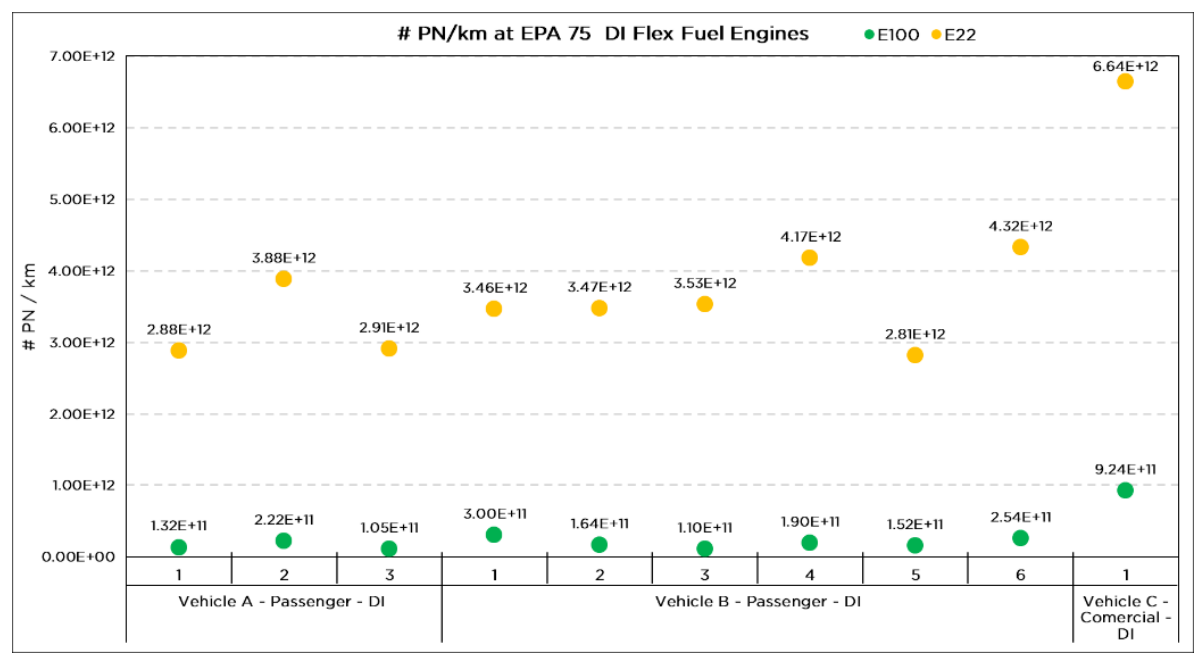

Figure 13: PN emissions with DI Flex-Fuel engines at EPA 75 driving cycle. 


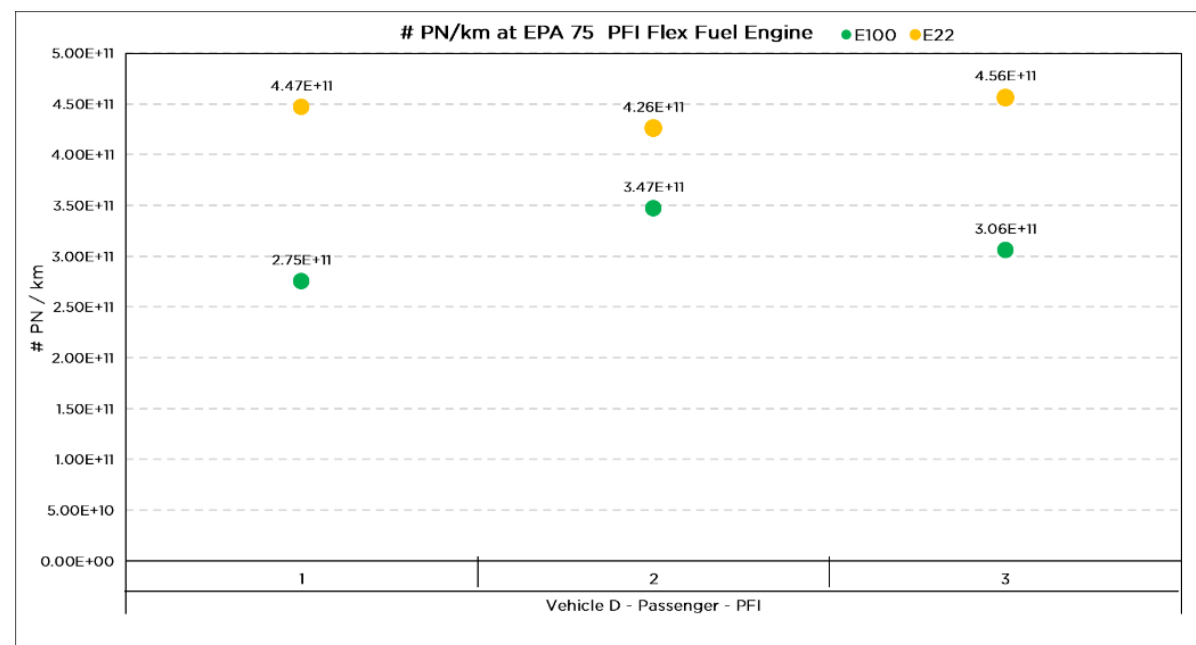

Figure 14: PN emissions with PFI Flex-Fuel engine at EPA 75 driving cycle.

The majority of the PN are generated during cold engine operation of the emissions test. Figure 15 shows the PN picks with both E100 and E22 fuels after cold start and during cold drivability transient accelerations.

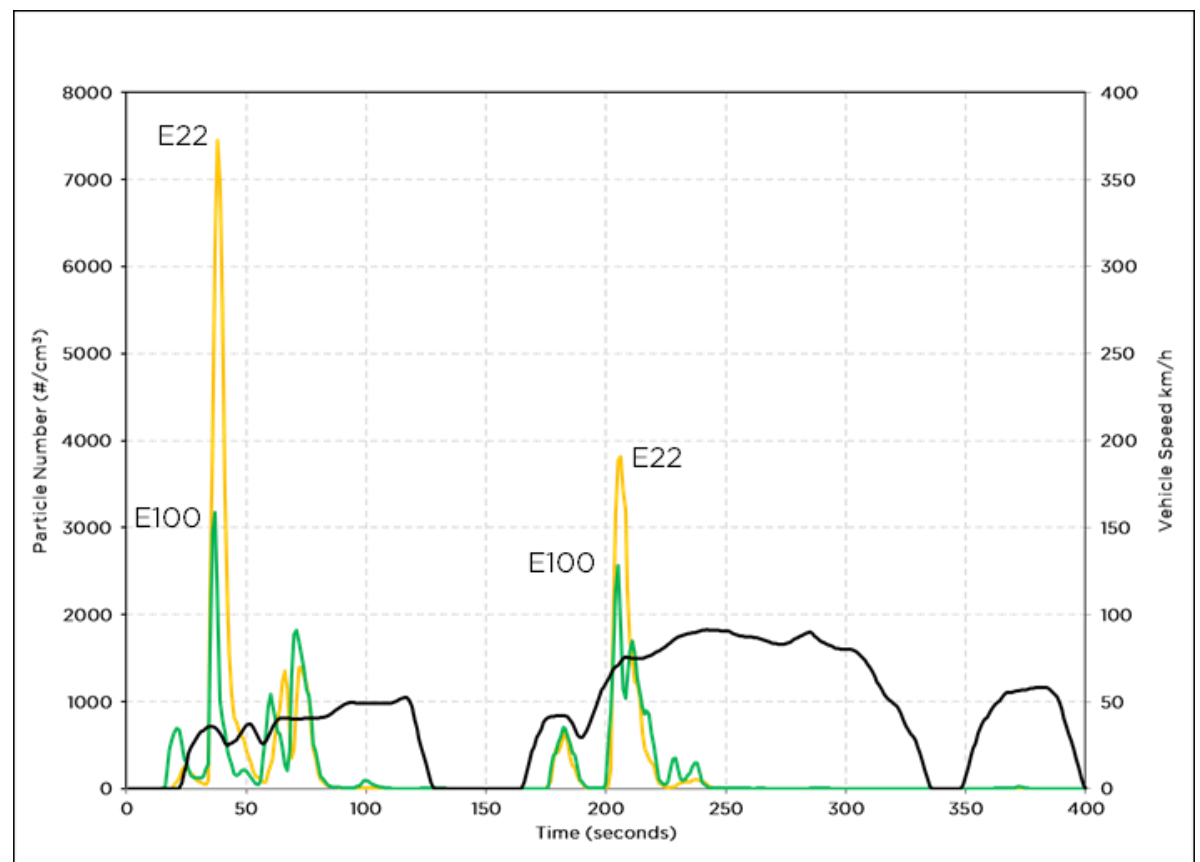

Figure 15: PN emissions on PFI Flex-Fuel engine at EPA 75 driving cycle.

Table 3 shows the average results with each Flex-Fuel engine technology, DI and PFI show that E100 fuel produces significantly less PN emissions. On both DI engines, E100 combustion produces about $90 \%$ less PN than E22. On PFI engine, PN emissions is much lower than seen on DI engines and E100 performance is even better, generating 30\% less than E22. 


\begin{tabular}{|c|c|c|c|c|}
\cline { 3 - 5 } \multicolumn{2}{c|}{} & \multicolumn{3}{c|}{ Average PN (\#/km) } \\
\hline Vehicle Category & Injection Type & E100 & E22 & $\%$ Difference \\
\hline Passenger & DI \#1 Flex & $1.8 E+11$ & $3.5 E+12$ & -94.81 \\
Comercial & DI \#2 Flex & $9.2 E+11$ & $6.6 E+12$ & -86.09 \\
\hline Passenger & PFI Flex & $3.1 E+11$ & $4.4 E+11$ & -30.16 \\
\hline
\end{tabular}

Table 3: Final average results with E100 and E22 fuels.

\section{CONCLUSIONS}

Tests confirmed that DI engines produce higher amount of particle numbers than PFI engines. However, E100 particle number in both DI engines is one order of magnitude lower than E22 emissions level and gets closer to the amount of PNs generated by the $\mathrm{PFI}$ engine.

Based on the results E100 is a strategic fuel for reducing and controlling PM pollution. Its application is a key factor for obtaining environmental, social and economic sustainability.

\section{REFERENCES}

[1] World Health Organization. Global Urban Ambient Air Pollution Database (update 2016). http://www.who.int/phe/health topics/outdoorair/databases/cities/en/ Access in May $20^{\text {th }}, 2018$.

[2] Irish Environmental Protection Agency. http://www.epa.ie/irelandsenvironment/air/ Access in May $20^{\text {th }}, 2018$.

[3] DALLMANN, T., FAÇANHA,C. INTERNATIONAL COMPARISON OF BRAZILIAN REGULATORY STANDARDS FOR LIGHT-DUTY VEHICLE EMISSIONS. White Paper, April 2017. Retrieved from https://www.theicct.org/publications/internationalcomparison-brazilian-regulatory-standards-light-duty-vehicle-emissions

[4] World Health Organization. Ambient air pollution in cities database. Retrieved from http://www.who.int/phe/health topics/outdoorair/databases/cities/en/ , 2014.

[5] SALVO, A. et. al. Reduced ultrafine Particle levels in São Paulo's atmosphere during shifts from gasoline to ethanol use. Nature Communications. Available at https://www.nature.com/articles/s41467-017-00041-5.pdf . Access in July 13 ${ }^{\text {th }}, 2018$.

[6] Particulate matter (PM) basics. Available at https://www.epa.gov/pmpollution/particulate-matter-pm-basics\#PM. Access in May $5^{\text {th }}, 2018$.

[7] European Environment Agency glossary. Available at https://www.eea.europa.eu/help/glossary\#c $4=10 \& c 0=a l l \& b$ start $=0 \& c 2=p m$. Access in May $5^{\text {th }}, 2018$. 
[8] JOHNSON, J. H. et al. A Review of Diesel Particulate Control Technology and Emissions Effects - 1992 Horning Memorial Award Lecture. SAE Technical Paper, 940233, 1994.

[9] KITTELSON, D. B. et al. Driving Down On-Highway Particulate Emissions. SAE paper, 2006-01-0916, 2006.

[10] KAYSER, J. Mounting evidence indicts fine-particle pollution. Available at http://www.precaution.org/lib/evidence indicts fine particles.science.050326.pdf.

Access in May $5^{\text {th }}, 2018$.

[11] TOLLEFSON, J. Soot a major contributor to climate change. Available at https://www.nature.com/news/soot-a-major-contributor-to-climate-change-1.12225.

Access in May $5^{\text {th }}, 2018$.

[12] BOND, T. C. et al. Bounding the role of black carbon in the climate system: A scientific assessment. Journal of Geophysical Research Atmospheres, paper 5380-5552, 2013.

[13] BULLIS, K. Cleaning up diesel trucks and cooking stoves could reduce climate change. Available at https://www.technologyreview.com/s/515961/cleaning-up-dieseltrucks-and-cooking-stoves-could-reduce-climate-change/. Access in May $5^{\text {th }}, 2018$.

[14] SMITH, O.I. Fundamentals of soot formation in flames with application to diesel engine particulate emissions. Prog. Energy Combust. Sci., vol. 7, pp 275-291, 1981. [15] KETTERER, J. An Introduction to Particulate Matter Emissions. Internal General Motors, 2016.

[16] Boing, M. et al. Soot Formation in Premixed C2H4 Flat Flames at Elevated Pressure. The Twenty Third Symposium (International) on Combustion, The Combustion Institute, Pittsburgh, PA, pp 1581-1587, 1990.

[17] Pires da Cruz, A. Fundmental Aspects of Gas Phase Combustion. IFP-School Master Degree Formation, 2009-2010.

[18] WHITAKER, P. et al. Measures to Reduce Particulate Emissions from Gasoline DI engines. SAE International Journal of Engines, v. 4, n. 1, paper 2011-01-1219, 2011.

\section{ACKNOWLEDGMENTS}

The authors gratefully acknowledge General Motors - Mercosul, which provided all resources and support for the accomplishment of this work at GM Cruz Alta Proving Ground. AVL South America for providing complementary technical information of the PNC model AVL 489. The first author extends also the acknowledgments to the ProRectory of Research and Graduate Studies of PUC-CAMPINAS who has provided support and technical background as part of the Sustainability Master Degree Course.

\section{ABREVIATIONS}

\begin{tabular}{|l|l|}
\hline CARB & California Air Resources Board \\
\hline CO & Carbon Monoxide \\
\hline DI & Direct Injection \\
\hline E100 & Hydrated Ethanol Fuel \\
\hline
\end{tabular}




\begin{tabular}{|c|c|}
\hline E22 & Gasoline with $22 \%$ anhydrous ethanol \\
\hline EEA & European Environment Agency \\
\hline EPA & US Environmental Protection Agency \\
\hline EURO $5 \mathrm{~b}$ & European Emission Standard stage $5 \mathrm{~b}$ \\
\hline EURO 6 & European Emission Standard stage 6 \\
\hline EURO 6c & European Emission Standard stage $6 \mathrm{c}$ \\
\hline FTP & US Federal Test Procedure \\
\hline GDI & Gasoline Direct \\
\hline L6 & Current emissions limits phase of PROCONVE \\
\hline LEV III & California light-duty vehicle emission standards \\
\hline NBR 6601 & Brazilian city driving test standard \\
\hline NEDC & New European Driving Cycle \\
\hline NOx & Nitrogen Oxide \\
\hline PFI & Port Fuel Injection \\
\hline PM & Particulate Matter \\
\hline $\mathbf{P} \mathbf{M}_{0.1}$ & Particulate Matter diameter $<0.10 \mu \mathrm{m}$ \\
\hline PM 2.5 & Particulate Matter diameter $<2.5 \mu \mathrm{m}$ \\
\hline PM 10 & Particulate Matter diameter $<10 \mu \mathrm{m}$ \\
\hline PMP & Particulate Measurement Protocol \\
\hline PN & Particle Number \\
\hline PROCONVE & Program for Control of Air Pollution by Automotive Vehicles \\
\hline RDE & Real Driving Emissions \\
\hline SO2 & Sulfur Dioxide \\
\hline SO4 & Sulfate \\
\hline SOF & Soluble organic fraction \\
\hline SOL & Solid carbon cores \\
\hline STOICH & Stoichiometric mixture \\
\hline Tier III & US federal exhaust emission standards for light-duty vehicles \\
\hline US & United States of America \\
\hline WHO & World Health Organization \\
\hline WLTP & Worldwide harmonized Light Vehicles Test Procedure \\
\hline
\end{tabular}

